\title{
Cerebral microbleeds and iron depletion of dentate nuclei in ataxia-telangiectasia
}

Figure 1 Cerebellar atrophy and cerebral microbleeds in ataxia-telangiectasia
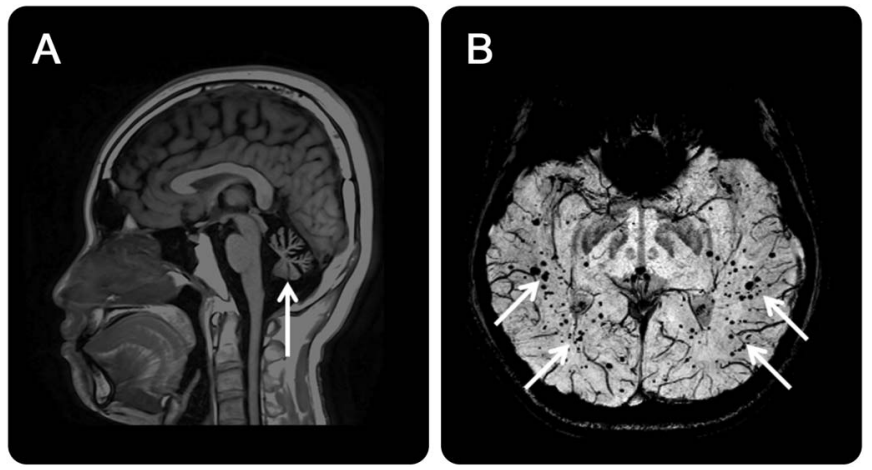

(A) T1-weighted MRI shows cerebellar atrophy (arrow). (B) Susceptibility-weighted images (SWI) show punctate signal voids scattering throughout the normal-sized cerebrum (arrows), suggesting microbleeds with hemosiderin deposits, which are related to telangiectatic vessels present in the patient with ataxia-telangiectasia.

Figure 2 Iron depletion of dentate nuclei in ataxia-telangiectasia
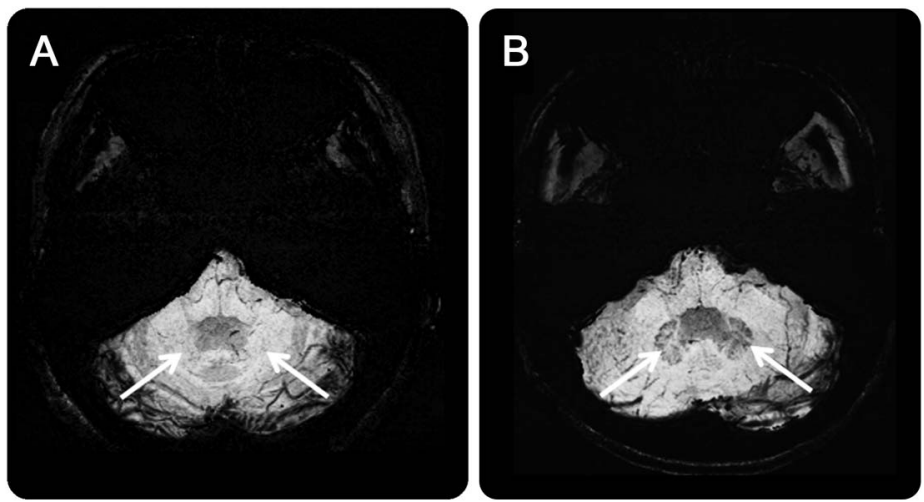

(A) Susceptibility-weighted images (SWI) reveal an absence of hypointensity of the iron signal in the dentate nuclei of the patient with ataxia-telangiectasia (arrows) compared to an age- and sex-matched normal control participant (B), whereas the dentate nuclei with a typical dark signal related to iron deposits are remarkably visible in SWI (arrows).

A 27-year-old man had been diagnosed with ataxia-telangiectasia at age 13 years. He had ocular telangiectasia and motor ataxia, with incoordination of head and eyes in lateral gaze. Laboratory data revealed deficiency of immunoglobulin and elevated $\alpha$-fetoprotein. MRI demonstrated cerebellar atrophy and cerebral microbleeds ${ }^{1}$ (figure 1); the dentate nuclei had deficient iron signals, which otherwise should be visible as hypointensities in susceptibility-weighted imaging (figure 2). Iron depletion in dentate nuclei is a novel finding and could be explained by the blockage of axonal iron transport in the olivocerebello-olivary loop. ${ }^{2}$

Hua-Shan Liu, PhD, Yung-Chieh Chen, MD, Cheng-Yu Chen, MD

From the School of Biomedical Engineering, College of Biomedical Engineering, Taipei Medical University (H.-S.L., C.-Y.C.); Department of Medical Imaging, Taipei Medical University Hospital (H.-S.L., C.-Y.C.); Department of Radiology, School of Medicine, College of Medicine, Taipei Medical University (C.-Y.C.); Graduate Institute of Clinical Medicine, College of Medicine, Taipei Medical 
University (H.-S.L., C.-Y.C.); Translational Imaging Research Center, College of Medicine, Taipei Medical University (H.-S.L.,C.-Y.C.); Department of Biomedical Imaging and Radiological Sciences, National Yang-Ming University (Y.-C.C.), Taipei, Taiwan.

Author contributions: Hua-Shan Liu: study concept and design, drafting manuscript, acquisition and analysis of data, designing figures. Yung-Chieh Chen: clinical data collection and analysis of data. Cheng-Yu Chen: study concept and design, critically reviewing and revising manuscript for intellectual content, study supervision.

Study funding: Hua-Shan Liu was supported by Taipei Medical University (grants TMU103-AE1-B29 and 104TMU-TMUH-03) and Ministry of Science and Technology, ROC (grant MOST105-2218-E-038-003-MY2). Cheng-Yu Chen was supported by Ministry of Science and Technology, ROC (grants MOST104-2314-B-038-051-MY3 and MOST104-2923-B-038-003-MY3) and Health and Welfare Surcharge of Tobacco Products (grant MOHW105-TDU-B-212-134001).

Disclosure: The authors report no disclosures relevant to the manuscript. Go to Neurology.org for full disclosures.

Correspondence to Dr. C.-Y. Chen: sandy0928@seed.net.tw

1. Lin DD, Barker PB, Lederman HM, Crawford TO. Cerebral abnormalities in adults with ataxia-telangiectasia. AJNR Am J Neuroradiol 2014;35:119-123.

2. Kim SJ, Lee JH, Suh DC. Cerebellar MR changes in patients with olivary hypertrophic degeneration. AJNR Am J Neuroradiol 1994;15:1715-1719.

\section{WriteClick ${ }^{\circledR}$ rapid online correspondence}

Have a comment on a recent $N e u r o l o g y{ }^{\circledR}$ article you would like to share? Now it is easier and more convenient. Neurology.org has launched WriteClick on the home page and sidebars of each article to encourage remarks and debate among users.

WriteClick is restricted to comments about studies published in Neurology within the last eight weeks.

Learn more at Neurology.org/letters

\section{AAN is Committed to Making a Difference: 2017 AAN Research Program}

The AAN's ambitious 2017 AAN Research Program offers 20 opportunities, including two new AAN-funded awards: $\$ 450,000$ for junior investigators interested in clinical, translational, or basic research; and $\$ 130,000$ for basic science research training.

Two additional non disease-specific scholarships are available in clinical and practice-based research; additional targeted funding opportunities include support for research in ALS, Alzheimer disease, ataxia, epilepsy, multiple sclerosis, muscular dystrophy, Parkinson disease, stroke, and Tourette syndrome.

Visit AAN.com/view/ResearchProgram to learn more and apply by the October 1, 2016, deadline!

The AAN is committed to making a profound difference in the lives of researchers by promoting neurology and neuroscience research and training, which in turn will make a difference in the lives of patients with brain disease. 


\section{Neurology}

\section{Cerebral microbleeds and iron depletion of dentate nuclei in ataxia-telangiectasia Hua-Shan Liu, Yung-Chieh Chen and Cheng-Yu Chen \\ Neurology 2016;87;1062-1063 \\ DOI 10.1212/WNL.0000000000003066}

This information is current as of September 5, 2016

\begin{tabular}{|c|c|}
\hline $\begin{array}{l}\text { Updated Information \& } \\
\text { Services }\end{array}$ & $\begin{array}{l}\text { including high resolution figures, can be found at: } \\
\text { http://n.neurology.org/content/87/10/1062.full }\end{array}$ \\
\hline References & $\begin{array}{l}\text { This article cites } 2 \text { articles, } 2 \text { of which you can access for free at: } \\
\text { http://n.neurology.org/content/87/10/1062.full\#ref-list-1 }\end{array}$ \\
\hline Citations & $\begin{array}{l}\text { This article has been cited by } 1 \text { HighWire-hosted articles: } \\
\text { http://n.neurology.org/content/87/10/1062.full\#\#otherarticles }\end{array}$ \\
\hline Subspecialty Collections & $\begin{array}{l}\text { This article, along with others on similar topics, appears in the } \\
\text { following collection(s): } \\
\text { All Education } \\
\text { http://n.neurology.org/cgi/collection/all_education } \\
\text { MRI } \\
\text { http://n.neurology.org/cgi/collection/mri }\end{array}$ \\
\hline Permissions \& Licensing & $\begin{array}{l}\text { Information about reproducing this article in parts (figures,tables) or in } \\
\text { its entirety can be found online at: } \\
\text { http://www.neurology.org/about/about_the_journal\#permissions }\end{array}$ \\
\hline Reprints & $\begin{array}{l}\text { Information about ordering reprints can be found online: } \\
\text { http://n.neurology.org/subscribers/advertise }\end{array}$ \\
\hline
\end{tabular}

Neurology ${ }^{\circledR}$ is the official journal of the American Academy of Neurology. Published continuously since 1951, it is now a weekly with 48 issues per year. Copyright @ 2016 American Academy of Neurology. All rights reserved. Print ISSN: 0028-3878. Online ISSN: 1526-632X.

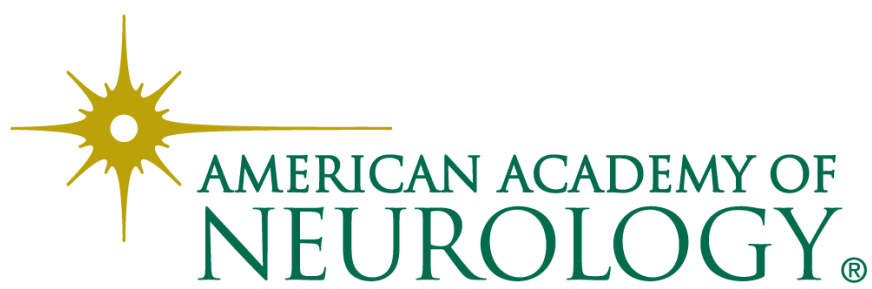

